\title{
IMMUNE STATUS OF PATIENTS WITH LUNG TUBERCULOSIS AND ALCOHOL CONSUMPTION
}

\author{
Maryna Kochuieva ${ }^{1,2}$ \\ kochuevamarina@gmail.com \\ Ivan Hrek $\boldsymbol{k}^{1,2}$ \\ grek.ivan.md@gmail.com \\ Olena Klimova \\ Zaycev $V . T$. Institute of General and Emergency surgery of the National academy of \\ medical sciences of Ukraine \\ 1, Balakireva entry, Kharkiv, Ukraine, 61103 \\ National Technical University "Kharkiv Polytechnic Institute" \\ 2, Kyrpychova str., Kharkiv, Ukraine, 61002 \\ Anton Rogozhyn ${ }^{1,2}$
pekin2006@ukr.net \\ Vasyl Kushnir ${ }^{1,2}$ \\ dikaryok@gmail.com
${ }^{1}$ Department of Phthisiology, Pulmonology and Family Medicine Kharkiv Medical Academy of Postgraduate Education, 58 Amosova str., Kharkiv, Ukraine, 61176
V. N. Karazin Kharkiv National University \\ ${ }^{2}$ Department of General and Clinical Immunology and Allergology \\ 6 Svobody sq., Kharkiv, Ukraine, 61022
}

\section{Abstract}

Tuberculosis is a great medical and social problem. An important risk factor for tuberculosis progress is the systematic use of alcohol. The relationship between alcohol intake and TB has been clear after numerous studies and meta-analyzes. However, there are still open questions about whether alcohol is the direct cause of TB development, which doses of alcohol have the greatest trigger value in progress of TB process, what kind of immunological reactions are significantly associated with alcohol intake and what immune background can determining role of alcohol in progression of TB infection. The features of the immune response in TB patients with different value of alcohol use remain poorly understood.

The aim of the research - to investigate the immune status in patients with firstly diagnosed pulmonary tuberculosis with various levels of alcohol consumption.

Materials and methods. We selected for participating in the study 102 males with tuberculosis and alcohol consumption. Examination of the patients included: clinical methods, chest X-ray, sputum tests, Alcohol Use Disorders Identification Test and immunological blood analysis.

Results. Patients with tuberculosis and alcohol consumption, have increase inflammatory response: higher level of stab neutrophils, CRP, ESR, as well as phagocyte activity, circulating immune complexes levels and medium molecular weight peptides levels. On the other hand we found decreasing of phagocytic number, index of phagocytosis completeness and differentiation clusters $\mathrm{CD}^{+}, \mathrm{CD}^{+}, \mathrm{CD}^{+}, \mathrm{CD}^{+}$of T-lymphocytes' sub-populations. The highest changes were observed in the group of alcohol abusers.

Conclusions. Patients with tuberculosis and alcohol intake, even at low levels of its consumption, have a dysregulation of their immune response. On the one hand, there is an increase of non-specific inflammatory reactions, and on the other - a situation, when antigen-presenting cells cannot adequately to process and present the antigen to phagocytes. This prevents the immune system from responding quickly, correctly evaluating and suppressing foreign agents.

Keywords: tuberculosis, alcohol, immune response, innate immunity, AUDIT. 


\section{Introduction}

Tuberculosis (TB) is a great medical and social problem of the healthcare system not only in Ukraine, but also throughout the world. According to WHO report annually there are registered more than 10 million new cases of TB and more than 1.5 million people die. One of the most threatening features of modern TB infection is the growth of prevalence of resistant forms of M. tuberculosis (MBT) [1].

An important risk factor for TB progress is the systematic use of alcohol. According to published data, about $10 \%$ of TB cases are associated with alcohol intake [2]. The negative effects of alcohol we can found at all stages of TB infection progress. Firstly, initial reduce of host cellular immunity because of alcohol use is increases the risk of TB infection, next - alcohol consumption can be a factor of progress an active TB process (reactivation of latent TB infection) $[3,4,6]$. Alcohol consumption during treatment leads to heavier adverse reactions of anti-TB drugs, irregular medication intake, poor response to therapy and the formation of resistance [4, 5]. The systematic use of alcohol and alcohol addiction are predictors of active TB. The results of meta-analyzes showed that regular intake of alcohol from $40 \mathrm{~g}$ per day (in terms of ethanol) contributes to a three-fold increase the risk of TB [3].

The relationship between alcohol intake and the development of TB has been clear after numerous studies and meta-analyzes [2-6]. However, there are still open questions about whether alcohol is the direct cause of TB development, which doses of alcohol have the greatest trigger value in progress of TB process, what kind of immunological reactions are significantly associated with alcohol intake and what immune background can determining role of alcohol in progression of TB infection. The features of the immune response in TB patients with different value of alcohol use remain poorly understood.

The objective of the research - to investigate the immune status in patients with firstly diagnosed pulmonary TB (FDTB) and preserved sensitivity to anti-TB drugs with various levels of alcohol consumption.

\section{Materials and methods}

The study was performed in the period 2017-2019 at the tuberculosis institutions in Kharkov, Ukraine (Municipal Non-commercial Enterprise of the Kharkiv regional council "Regional TB dispensary No. 1", Municipal Non-commercial Enterprise of the Kharkov regional council "Regional Tuberculosis hospital No. 1", State Healthcare Institution "Regional Tuberculosis hospital No. 3"). The study included 102 patients with FDTB and alcohol use. All patients were at the beginning of the intensive phase of treatment and received standard four-component therapy (isoniazid, rifampicin, pyrazinamide, ethambutol) according to the recommendations of the current guidelines [7].

The criteria for inclusion in the study were as follows: male gender, age from 20 to 50 years (35.9 \pm 7.2 years), FDTB, the presence of MBT according to the results of sputum tests $(\mathrm{MBT}+)$, the absence of resistance to anti-TB drugs according to the results of drug tests sensitivity.

Patients were excluded from the study if they had a history of drug use, chronic diseases HIV, hepatitis, bronchial asthma, COPD, diabetes mellitus, systemic, autoimmune, oncological illness or mental disorders.

The study participants had a comprehensive clinical and laboratory examination. The diagnosis of TB was established by the results of an X-ray examination of the chest and laboratory sputum tests (microscopic, cultural and molecular genetic) according to the recommendations of the current guideline [7].

The 10-item Alcohol Use Disorders Identification Test (AUDIT) is used to assess lifetime hazardous and harmful patterns of alcohol use [8]. AUDIT results were read according to the user manual: 0-7 points - low level of consumption, 8-15 points - hazardous level of consumption, 16-19 points - harmful level, 20+ points - possible alcohol dependence. 
According to the results of the AUDIT test, patients were distributed into three groups. To group 1 belonged persons who scored $0-7$ points $(n=30)$, to group $2-8-15$ points $(n=44)$ and to group 3 (abusers) - 16 points or more $(n=28)$. It should be noted that at group 1 there were $2(6.7 \%)$ people who did not score a single point. At group 3, the maximum number of points scored was 32, while $5(17.9 \%)$ patients had a score of more than 20 points, which corresponded to a possible alcohol dependence. Groups were comparable in age.

To evaluate the state of the immune system, immunological studies were carried out. The barrier function of phagocytes was evaluated according to the phagocytic activity of peripheral blood neutrophils by light microscopy with determination of phagocytic index (PI) (number of cells involved in phagocytosis), phagocytic number (PN) (average number of absorbed microbes by one neutrophil) and the index of phagocytosis completeness (IPC) (the digesting ability of neutrophils). Sub-populations of T-lymphocytes were evaluated by expression of differentiation clusters $\mathrm{CD}^{+}, \mathrm{CD}^{+}, \mathrm{CD}^{+}, \mathrm{CD}^{+}$by immunofluorescence method using dye-labeled monoclonal antibodies manufactured by «Sorbent», Russia (stained cells were counted using a fluorescence microscope). The concentration of circulating immune complexes (CIC) and the CIC constant were determined by selective precipitation of antigen-antibody complexes in polyethylene glycol followed by photometric measurement of the optical density of the precipitate. The content of medium molecular weight peptides (MMWP) in blood serum was determined using spectrophotometry after preliminary precipitation of coarsely dispersed proteins with trichloroacetic acid.

The study was conducted in accordance with the requirements of good clinical practice, the Council of Europe Convention on Human Rights and Biomedicine, the Helsinki Declaration of the World Medical Association and approved by the local ethics committee of the Kharkiv Medical Academy of Postgraduate Education (protocol No. 1, from 18.02.2020). All patients signed informed consent for participating in the clinical trial.

The obtained data were processed by Statistica software. Quantitative data are presented as mean values (M) and standard deviations (SD). For comparison of values between groups, Student's t-test and Wilcoxon test were used. To describe qualitative variation, we used the frequency at which the traits were assessed in the group. The critical significance level of statistical significance at the null hypothesis test was assumed to be 0.05 .

\section{Results and discussion}

The inflammatory response indicators in patient groups are presented in Table 1.

When analyzing the data obtained, it was found that in patients with FDTB with an increase of alcohol consumption, is an increase levels of stab neutrophils, CRP and ESR is observed. The maximum values are indicated in the group of people who abuse alcohol.

When we assessing the parameters of the cellular link of the primary immune response at the beginning of the intensive phase of treatment in patients with FDTB, a significant $(\mathrm{p}<0.05)$ increase in phagocyte activity was established compared with the reference values (Table 2). However, as the level of alcohol consumption in the comparison groups increased, there was a tendency toward a decrease in the PI and PN levels. At the same time, the PN index of group 3 did not have significant differences with reference values $(\mathrm{p}=0.158)$.

IPC indices in the comparison groups were statistically significantly lower $(p<0.001)$ of reference values. The minimum mean value of the IPC in the group of alcohol abusers.

In all observed groups of FDTB patients with alcohol consumption, significantly lower $\mathrm{CD}^{+}$levels were found, which indicated a decrease in their ability to recognize and bind antigens with T-lymphocytes. At the same time, a decrease in the level of CD2 $2^{+}$molecules was not detected (Table 3).

In all groups of patients, a statistically significant $(p<0.05)$ decrease in the number of $\mathrm{CD}^{+}$ and the level of $\mathrm{CD}^{+} \mathrm{T}$-cells was found. The lowest average values of both indicators was determined in patients of the 3rd group. 
Table 1

The inflammatory response in patients of comparison groups

\begin{tabular}{|c|c|c|c|c|c|}
\hline Indicators & Reference value & $\begin{array}{c}\text { Group } 1 \\
(n=30)\end{array}$ & $\begin{array}{c}\text { Group } 2 \\
(n=44)\end{array}$ & $\begin{array}{c}\text { Group } 3 \\
(n=28)\end{array}$ & p-value \\
\hline Age, years & & $37.67 \pm 8.61$ & $37.14 \pm 7.13$ & $34.18 \pm 9.46$ & $\begin{array}{l}\mathrm{p}_{1-2}=0.455 \\
\mathrm{p}_{1-3}=0.295 \\
\mathrm{p}_{2-3}=0.247\end{array}$ \\
\hline $\mathrm{ESR}, \mathrm{mm} / \mathrm{h}$ & $8.64 \pm 4.34$ & $8 \pm 8.59$ & $18.07 \pm 28.69$ & $54.86 \pm 3.98$ & $\begin{array}{l}\mathrm{p}_{\mathrm{r}-1}=0.617 \\
\mathrm{p}_{\mathrm{r}-2}=0.637 \\
\mathrm{p}_{\mathrm{r}-3}<0.001 \\
\mathrm{p}_{1-2}=0.36 \\
\mathrm{p}_{1-3}<0.001 \\
\mathrm{p}_{2-3}<0.001\end{array}$ \\
\hline WBC, cells/1 & $6.98 \pm 1.46$ & $5.5 \pm 1.6$ & $6.45 \pm 1.2$ & $6.6 \pm 1.37$ & $\begin{array}{l}\mathrm{p}_{\mathrm{r}-1}=0.002 \\
\mathrm{p}_{\mathrm{r}-2}=0.137 \\
\mathrm{p}_{\mathrm{r}-3}=0.475 \\
\mathrm{p}_{1-2}=0.014 \\
\mathrm{p}_{1-3}=0.029 \\
\mathrm{p}_{2-3}=0.134\end{array}$ \\
\hline Band neutrophil, \% & $3.12 \pm 1.64$ & $4.63 \pm 1.9$ & $3.89 \pm 1.53$ & $5.07 \pm 1.39$ & $\begin{array}{l}\mathrm{p}_{\mathrm{r}-1}=0.011 \\
\mathrm{p}_{\mathrm{r}-2}=0.09 \\
\mathrm{p}_{\mathrm{r}-3}<0.001 \\
\mathrm{p}_{1-2}=0.283 \\
\mathrm{p}_{1-3}=0.461 \\
\mathrm{p}_{2-3}<0.001\end{array}$ \\
\hline $\begin{array}{c}\text { Segmented } \\
\text { neutrophil, \% }\end{array}$ & $61.52 \pm 5.87$ & $55.73 \pm 8.28$ & $56.11 \pm 8.08$ & $60.64 \pm 1.47$ & $\begin{array}{l}\mathrm{p}_{\mathrm{r}-1}=0.003 \\
\mathrm{p}_{\mathrm{r}-2}=0.02 \\
\mathrm{p}_{\mathrm{r}-3}=0.337 \\
\mathrm{p}_{1-2}=0.869 \\
\mathrm{p}_{1-3}=0.023 \\
\mathrm{p}_{2-3}=0.068\end{array}$ \\
\hline Monocytes, \% & $6.48 \pm 2.58$ & $7.47 \pm 2.43$ & $5.86 \pm 1.94$ & $6.5 \pm 1.86$ & $\begin{array}{l}\mathrm{p}_{\mathrm{r}-1}=0.741 \\
\mathrm{p}_{\mathrm{r}-2}=0.18 \\
\mathrm{p}_{\mathrm{r}-3}=0.603 \\
\mathrm{p}_{\mathrm{r}-2}=0.056 \\
\mathrm{p}_{\mathrm{r}-3}=0.087 \\
\mathrm{p}_{2-3}=0.360\end{array}$ \\
\hline $\mathrm{CRP}, \mathrm{mg} / \mathrm{l}$ & $2.36 \pm 2.1$ & $2.6 \pm 3.8$ & $11.18 \pm 17.7$ & $26.8 \pm 11.8$ & $\begin{array}{l}\mathrm{p}_{\mathrm{r}-1}=0.548 \\
\mathrm{p}_{\mathrm{r}-2}=0.014 \\
\mathrm{p}_{\mathrm{r}-3}<0.001 \\
\mathrm{p}_{1-2}=0.018 \\
\mathrm{p}_{1-3}<0.001 \\
\mathrm{p}_{2-3}=0.002\end{array}$ \\
\hline
\end{tabular}

Note: the index ${ }_{r}$ of the p-value corresponds to the reference value. The indices ${ }_{1}{ }_{2}$ and ${ }_{3}$ correspond to the numbers of the comparison groups 
Table 2

Indicators of phagocytic activity in patients of comparison groups

\begin{tabular}{|c|c|c|c|c|c|}
\hline Indicators & Reference value & $\begin{array}{c}\text { Group } 1 \\
(n=30)\end{array}$ & $\begin{array}{c}\text { Group } 2 \\
(n=44)\end{array}$ & $\begin{array}{c}\text { Group } 3 \\
(\mathrm{n}=\mathbf{2 8})\end{array}$ & p-value \\
\hline $\begin{array}{c}\text { PI, } \\
\text { (after } 30 \mathrm{~min}), \%\end{array}$ & $79.92 \pm 6.82$ & $89.5 \pm 4.38$ & $87.25 \pm 5.29$ & $85.46 \pm 9.24$ & $\begin{array}{l}\mathrm{p}_{\mathrm{r}-1}<0.001 \\
\mathrm{p}_{\mathrm{r}-2}=0.001 \\
\mathrm{p}_{\mathrm{r}-3}=0.032 \\
\mathrm{p}_{1-2}=0.154 \\
\mathrm{p}_{1-3}=0.124 \\
\mathrm{p}_{2-3}=0.178\end{array}$ \\
\hline PN & $3.4 \pm 0.62$ & $4.59 \pm 0.76$ & $4.03 \pm 0.64$ & $3.97 \pm 1.45$ & $\begin{array}{c}\mathrm{p}_{\mathrm{r}-1}<0.001 \\
\mathrm{p}_{\mathrm{r}-2}=0.007 \\
\mathrm{p}_{\mathrm{r}-3}=0.158 \\
\mathrm{p}_{1-2}=0.005 \\
\mathrm{p}_{1-3}=0.06 \\
\mathrm{p}_{2-3}=0.954\end{array}$ \\
\hline IPC & $1.13 \pm 0.07$ & $0.99 \pm 0.12$ & $1.02 \pm 0.11$ & $0.97 \pm 0.12$ & $\begin{array}{l}\mathrm{p}_{\mathrm{r}-1}<0.001 \\
\mathrm{p}_{\mathrm{r}-2}<0.001 \\
\mathrm{p}_{\mathrm{r}-3}<0.001 \\
\mathrm{p}_{1-2}=0.445 \\
\mathrm{p}_{1-3}=0.487 \\
\mathrm{p}_{2-3}=0.153\end{array}$ \\
\hline
\end{tabular}

Table 3

T-lymphocyte subpopulation levels in patients of comparison groups

\begin{tabular}{|c|c|c|c|c|c|}
\hline Indicators & Reference value & $\begin{array}{c}\text { Group } 1 \\
(\mathrm{n}=\mathbf{3 0})\end{array}$ & $\begin{array}{c}\text { Group } 2 \\
(n=44)\end{array}$ & $\begin{array}{c}\text { Group } 3 \\
(n=28)\end{array}$ & p-value \\
\hline 1 & 2 & 3 & 4 & 5 & 6 \\
\hline $\begin{array}{c}\text { Lymphocyte }\left(10^{9}\right) \\
\text { cells } / 1\end{array}$ & $2.44 \pm 0.71$ & $1.57 \pm 0.49$ & $1.93 \pm 0.47$ & $1.45 \pm 0.39$ & $\begin{array}{l}\mathrm{p}_{\mathrm{r}-1}<0.001 \\
\mathrm{p}_{\mathrm{r}-2}=0.009 \\
\mathrm{p}_{\mathrm{r}-3}<0.001 \\
\mathrm{p}_{1-2}=0.057 \\
\mathrm{p}_{1-3}=0.215 \\
\mathrm{p}_{2-3}=0.004\end{array}$ \\
\hline $\mathrm{CD} 2^{+}$, abs. & $416.7 \pm 59.3$ & $440.6 \pm 199.2$ & $538.2 \pm 176.7$ & $380 \pm 177.8$ & $\begin{array}{l}\mathrm{p}_{\mathrm{r}-1}=0.677 \\
\mathrm{p}_{\mathrm{r}-2}=0.007 \\
\mathrm{p}_{\mathrm{r}-3}=0.312 \\
\mathrm{p}_{1-2}=0.150 \\
\mathrm{p}_{1-3}=0.175 \\
\mathrm{p}_{2-3}=0.018\end{array}$ \\
\hline $\mathrm{CD}^{+}$, abs. & $1050 \pm 281.9$ & $684.7 \pm 265.3$ & $831.8 \pm 237.6$ & $673.9 \pm 235.2$ & $\begin{array}{l}\mathrm{p}_{\mathrm{r}-1}<0.001 \\
\mathrm{p}_{\mathrm{r}-2}=0.005 \\
\mathrm{p}_{\mathrm{r}-3}<0.001 \\
\mathrm{p}_{1-2}=0.077 \\
\mathrm{p}_{1-3}=0.707 \\
\mathrm{p}_{2-3}=0.107\end{array}$ \\
\hline $\mathrm{CD}^{+}$, abs. & $609.8 \pm 123.6$ & $448 \pm 219.5$ & $470.7 \pm 141.9$ & $428.6 \pm 191.8$ & $\begin{array}{l}\mathrm{p}_{\mathrm{r}-1}=0.005 \\
\mathrm{p}_{\mathrm{r}-2}=0.002 \\
\mathrm{p}_{\mathrm{r}-3}=0.002 \\
\mathrm{p}_{1-2}=0.681 \\
\mathrm{p}_{1-3}=0.829 \\
\mathrm{p}_{2-3}=0.471\end{array}$ \\
\hline
\end{tabular}


Continuation of Table 3

\begin{tabular}{|c|c|c|c|c|c|}
\hline 1 & 2 & 3 & 4 & 5 & 6 \\
\hline $\mathrm{CD}^{+}$, abs. & $306.9 \pm 57.7$ & $236.7 \pm 99.9$ & $361.1 \pm 228.2$ & $245.4 \pm 54.5$ & $\begin{array}{l}\mathrm{p}_{\mathrm{r}-1}=0.008 \\
\mathrm{p}_{\mathrm{r}-2}=0.874 \\
\mathrm{p}_{\mathrm{r}-3}<0.001 \\
\mathrm{p}_{1-2}=0.128 \\
\mathrm{p}_{1-3}=0.957 \\
\mathrm{p}_{2-3}=0.471\end{array}$ \\
\hline $\mathrm{CD}^{+} / \mathrm{CD}^{+}$ & $2.5 \pm 0.26$ & $2.1 \pm 0.95$ & $2.1 \pm 0.6$ & $1.7 \pm 0.6$ & $\begin{array}{l}\mathrm{p}_{\mathrm{r}-1}=0.125 \\
\mathrm{p}_{\mathrm{r}-2}=0.063 \\
\mathrm{p}_{\mathrm{r}-3}<0.001 \\
\mathrm{p}_{1-2}=0.837 \\
\mathrm{p}_{1-3}=0.118 \\
\mathrm{p}_{2-3}=0.122\end{array}$ \\
\hline
\end{tabular}

Statistically significant $(\mathrm{p}<0.05)$ higher levels of CIC concentrations were revealed in all groups of patients with FDTB who use alcohol, compared with reference values (Table 4). The highest average CIC was determined in the group of alcohol abusers. In the same group, the lowest CIC constants were found. Reduced values of the CIC constant in all three groups of patients $(\mathrm{p}<0.001)$ indicated about conformational changes in the CIC (their small size) and the possibility of their deposition in tissues. High concentrations of CICs in the blood serum of the examined patients also indicated the presence of severe intoxication on the background of the combined effect of TB infection and alcohol consumption.

Table 4

The indicators of the humoral immunity in comparison groups

\begin{tabular}{|c|c|c|c|c|c|}
\hline Indicators & Reference value & $\begin{array}{c}\text { Group } 1 \\
(n=30)\end{array}$ & $\begin{array}{c}\text { Group } 2 \\
(n=44)\end{array}$ & $\begin{array}{c}\text { Group } 3 \\
(n=28)\end{array}$ & p-value \\
\hline CIC, units & $76.2 \pm 13.2$ & $118 \pm 62.7$ & $147.6 \pm 69.5$ & $169.5 \pm 117.5$ & $\begin{array}{c}\mathrm{p}_{\mathrm{r}-1}=0.007 \\
\mathrm{p}_{\mathrm{r}-2}<0.001 \\
\mathrm{p}_{\mathrm{r}-3}<0.001 \\
\mathrm{p}_{1-2}=0.04 \\
\mathrm{p}_{1-3}=0.063 \\
\mathrm{p}_{2-3}=0.5\end{array}$ \\
\hline CIC-constanta & $1.3 \pm 0.2$ & $0.9 \pm 0.1$ & $1.02 \pm 0.04$ & $0.9 \pm 0.09$ & $\begin{array}{l}\mathrm{p}_{\mathrm{r}-1}<0.001 \\
\mathrm{p}_{\mathrm{r}-2}<0.001 \\
\mathrm{p}_{\mathrm{r}-3}<0.001 \\
\mathrm{p}_{1-2}=0.315 \\
\mathrm{p}_{1-3}=0.702 \\
\mathrm{p}_{2-3}=0.534\end{array}$ \\
\hline MMWP & $0.223 \pm 0.053$ & $0.378 \pm 0.047$ & $0.362 \pm 0.095$ & $0.427 \pm 0.045$ & $\begin{array}{l}\mathrm{p}_{\mathrm{r}-1}<0.001 \\
\mathrm{p}_{\mathrm{r}-2}<0.001 \\
\mathrm{p}_{\mathrm{r}-3}<0.001 \\
\mathrm{p}_{1-2}=0.951 \\
\mathrm{p}_{1-3}=0.006 \\
\mathrm{p}_{2-3}=0.002\end{array}$ \\
\hline
\end{tabular}

The maximum increase of the mean MMWP concentration was observed in the group of patients who abuse alcohol. Moreover, this indicator at group 3 was significantly higher compared to the groups 1 and 2, and the average concentration of MMWP at groups of patients 1 and 2 was significantly higher than the reference values. 


\section{Discussions}

In our study, an increase in blood levels of band neutrophils, ESR and CRP showed possible pro-inflammatory effects [9-11] of alcoholization in patients with tuberculosis.

One of the most important defense mechanisms against TB infection related to the system of non-specific immunoresistance is the ability of neutrophils and mononuclear cells to phagocytosis. The results of our study showed increased activity of phagocytes in all groups of patients. This indicated an increased ability of antigen-presenting cells to chemotaxis and adhesion. However, with increasing alcohol consumption, there was a tendency to decrease the ability of neutrophils to absorb antigens. One of the main features of TB infection is the presence of incomplete phagocytosis of the MBT $[12,13]$. In our study, patients of all groups, IPC was below the reference values. Moreover, this indicator decreased with increasing alcohol consumption, which indicated a negative effect of ethanol on the ability of neutrophils to endocytosis.

The T-lymphocyte system plays the role of a regulatory mechanism in the implementation of immune response. The surface molecule of intercellular adhesion $\mathrm{CD} 2^{+}$provides both adhesion between T-cells and their targets, and subsequent activation of T-cells. CD3 ${ }^{+}$are involved in the recognition of antigens, their binding to T-lymphocytes and signal transmission [14, 15]. In our study, a significant decrease in $\mathrm{CD}^{+}$levels was observed in all groups of patients. This indicates a decrease in the ability of T-lymphocytes to recognize and bind antigens.

It was found that $\mathrm{CD}^{+}-$are involved in antigen-induced activation of T-cells, regulation of adhesion of $\mathrm{T}$ and B-lymphocytes. CD8+ act as a co-receptor in the activation of T-cells, facilitate the recognition of cell-related MHC class I antigens and involved in recognition of antigenic peptides $[16,17]$. In our study, a decrease in the levels of these indicators of the T-cell immunity in patients with FDTB testified to possible impairment of the adhesion cascade, defectiveness of subsequent antibody production by B-cells, and general dysregulation of cell-mediated immunity.

It has been found that CICs of an antigen-antibody are constantly formed in the body and have a physiological defense mechanism leading to the rapid elimination of endogenous and exogenous agents by the reticuloendothelial system. With a lack of complement components, CICs are deposited mainly on the vascular wall and on structures expressing Fc-receptors, for example, on basement membranes. As a result, an immunocomplex pathology develops [18]. It is known that the presence of a bacterial infection in the body induces the accumulation of finely dispersed complexes on the basement membranes of the microvasculature and creates conditions for the longterm activation of complement proteins. Its leads to the deposition of CIC on the membranes and the development of inflammation. Long-term stress condition of this system by the presence of TB infection leads to a decrease of overall activity of the complement protein system. High concentrations of circulating immune complexes in the blood serum of the examined patients indicated the presence of severe intoxication because of the combined effect of tuberculosis infection and alcohol consumption.

MMWP are secondary endogenous toxins of a protein nature. Their appearance is associated with the activation of proteolytic enzymes in the blood and the violation of their elimination. It is known that an increase in the MMWP fraction is regarded as a sign of the development of endogenous intoxication in inflammatory processes [18-21].

The results of our study showed a significant increase level of MMWP in all groups and especially in the group abusing alcohol. This indicates a high level of intoxication associated with the combined effect of alcohol and TB infection.

Because of high biological activity of MMWP, the manifestations of the neurotoxic effects of peptides, inhibition of protein biosynthesis, inhibition of the enzymes activity, impaired oxidation and phosphorylation processes, and the occurrence of secondary immunosuppression are possible in patients of the studied groups [22].

Limitations of the study. The present research was aimed at studying only immunological changes (mainly the cellular component). The state of the humoral immunity link was not adequately covered. Clinical and radiological features, the level of quality of life and the state of the antioxidant defense system were also not discussed. 
Prospects for further research are aimed at a more detailed assessment of humoral immunity, the state of the oxidative stress-antioxidant defense system. It is also necessary to draw up clinical and radiological portraits of the studied groups and evaluate the impact of different alcohol consumption levels on the quality of life.

\section{Conclusions}

Thus, in groups of patients with FDTB and consume alcohol, even at low levels of its consumption, there is a sharp dysregulation of the immune response. On the one hand, there is an increase of non-specific inflammatory reactions, and on the other - a violation of the recognition of infectious antigens when antigen-presenting cells cannot adequately to process and present the antigen to phagocytes. This prevents the immune system from responding quickly, correctly evaluating and suppressing foreign agents. The highest level of immune response disorders is observed in the group of patients who abuse alcohol with a possible risk of developing alcohol dependence.

\section{Conflict of interests}

The authors declare that they have no conflicts of interest.

\section{References}

[1] Global tuberculosis report 2019 (2019). Geneva: World Health Organization. Available at: https://www.who.int/tb/publications/ global_report/en/

[2] Rehm, J., Samokhvalov, A. V., Neuman, M. G., Room, R., Parry, C., Lönnroth, K. et. al. (2009). The association between alcohol use, alcohol use disorders and tuberculosis (TB). A systematic review. BMC Public Health, 9(1). doi: http://doi.org/ 10.1186/1471-2458-9-450

[3] Simou, E., Britton, J., Leonardi-Bee, J. (2018). Alcohol consumption and risk of tuberculosis: a systematic review and meta-analysis. The International Journal of Tuberculosis and Lung Disease, 22 (11), 1277-1285. doi: http://doi.org/10.5588/ ijtld.18.0092

[4] Silva, D. R., Muñoz-Torrico, M., Duarte, R., Galvão, T., Bonini, E. H., Arbex, F. F. et. al. (2018). Risk factors for tuberculosis: diabetes, smoking, alcohol use, and the use of other drugs. Jornal Brasileiro de Pneumologia, 44 (2), 145-152. doi: http:// doi.org/10.1590/s1806-37562017000000443

[5] Duarte, R., Lönnroth, K., Carvalho, C., Lima, F., Carvalho, A. C. C., Muñoz-Torrico, M., Centis, R. (2018). Tuberculosis, social determinants and co-morbidities (including HIV). Pulmonology, 24 (2), 115-119. doi: http://doi.org/10.1016/j.rppnen. 2017.11.003

[6] Myers, B., Bouton, T. C., Ragan, E. J., White, L. F., McIlleron, H., Theron, D. et. al. (2018). Impact of alcohol consumption on tuberculosis treatment outcomes: a prospective longitudinal cohort study protocol. BMC Infectious Diseases, 18 (1). doi: http:// doi.org/10.1186/s12879-018-3396-y

[7] Unifikovanyi klinichnyi protocol pervynnoi, vtorynnoi (spetsializovanoi) ta tretynnoi (vysokospetsializovanoi) medychnoi dopomohy «Tuberkuloz» (2014). Zatverdzhenyi nakazom MOZ Ukrainy No. 620 04.09.2014 «Pro zatverdzhennia ta vprovadzhennia medyko-tekhnolohichnykh dokumentiv zi standartyzatsii medychnoi dopomohy pry tuberkulozi». Kyiv: MOZ Ukrainy. Available at: https://phc.org.ua/sites/default/files/uploads/files/dn_20141231_1039dod.pdf

[8] Babor, T., Higgins-Biddle, J. C., Saunders, J. B., Monteiro, M. G. (2001). Audit, the alcohol use disorders identification test: guidelines for use in primary care. Geneva: World Health Organization. Available at: https://apps.who.int/iris/bitstream/ handle/10665/67205/WHO_MSD_MSB_01.6a.pdf;jsessionid=41CE9E9FB04F71DF95D9874F0C180B4D?sequence=1

[9] Szabo, G., Saha, B. (2015). Alcohol's Effect on Host Defense. Alcohol research: current reviews, 37 (2), 159-170.

[10] González-Reimers, E. (2014). Alcoholism: A systemic proinflammatory condition. World Journal of Gastroenterology, 20 (40), 14660. doi: http://doi.org/10.3748/wjg.v20.i40.14660

[11] Kalejaiye, O., Getachew, B., Ferguson, C. L., Taylor, R. E., Tizabi, Y. (2017). Alcohol-Induced Increases in Inflammatory Cytokines Are Attenuated by Nicotine in Region-Selective Manner in Male Rats. Journal of Drug and Alcohol Research, 6, 1-6. doi: http://doi.org/10.4303/jdar/236036

[12] Pai, M., Behr, M. A., Dowdy, D., Dheda, K., Divangahi, M., Boehme, C. C. et. al. (2016). Tuberculosis. Nature Reviews Disease Primers, 2 (1). doi: http://doi.org/10.1038/nrdp.2016.76

[13] Simmons, J. D., Stein, C. M., Seshadri, C., Campo, M., Alter, G., Fortune, S. et. al. (2018). Immunological mechanisms of human resistance to persistent Mycobacterium tuberculosis infection. Nature Reviews Immunology, 18 (9), 575-589. doi: http:// doi.org/10.1038/s41577-018-0025-3 
[14] Alcover, A., Alarcón, B., Di Bartolo, V. (2018). Cell Biology of T Cell Receptor Expression and Regulation. Annual Review of Immunology, 36 (1), 103-125. doi: http://doi.org/10.1146/annurev-immunol-042617-053429

[15] Liu, L. L., Landskron, J., Ask, E. H., Enqvist, M., Sohlberg, E., Traherne, J. A. et. al. (2016). Critical Role of CD2 Co-stimulation in Adaptive Natural Killer Cell Responses Revealed in NKG2C-Deficient Humans. Cell Reports, 15 (5), $1088-1099$. doi: http://doi.org/10.1016/j.celrep.2016.04.005

[16] Jasenosky, L. D., Scriba, T. J., Hanekom, W. A., Goldfeld, A. E. (2015). T cells and adaptive immunity toMycobacterium tuberculosisin humans. Immunological Reviews, 264 (1), 74-87. doi: http://doi.org/10.1111/imr.12274

[17] Martin, M. D., Badovinac, V. P. (2018). Defining Memory CD8 T Cell. Frontiers in Immunology, 9. doi: http://doi.org/10.3389/ fimmu.2018.02692

[18] Singhania, A., Wilkinson, R. J., Rodrigue, M., Haldar, P., O’Garra, A. (2018). The value of transcriptomics in advancing knowledge of the immune response and diagnosis in tuberculosis. Nature Immunology, 19 (11), 1159-1168. doi: http:// doi.org/10.1038/s41590-018-0225-9

[19] Wen, Y., Mu, L., Shi, Y. (2016). Immunoregulatory functions of immune complexes in vaccine and therapy. EMBO Molecular Medicine, 8 (10), 1120-1133. doi: http://doi.org/10.15252/emmm.201606593

[20] Burel, J. G., Pomaznoy, M., Lindestam Arlehamn, C. S., Weiskopf, D., da Silva Antunes, R., Jung, Y. et. al. (2019). Circulating T cell-monocyte complexes are markers of immune perturbations. eLife, 8. doi: http://doi.org/10.7554/elife.46045

[21] Jacobs, A. J., Mongkolsapaya, J., Screaton, G. R., McShane, H., Wilkinson, R. J. (2016). Antibodies and tuberculosis. Tuberculosis, 101, 102-113. doi: http://doi.org/10.1016/j.tube.2016.08.001

[22] Stek, C., Allwood, B., Walker, N. F., Wilkinson, R. J., Lynen, L., Meintjes, G. (2018). The Immune Mechanisms of Lung Parenchymal Damage in Tuberculosis and the Role of Host-Directed Therapy. Frontiers in Microbiology, 9. doi: http:// doi.org/10.3389/fmicb.2018.02603

Received date 25.02.2020

Accepted date 17.03.2020

Published date 31.03.2020
(C) The Author(s) 2020

This is an open access article under the CC BY license (http://creativecommons.org/licenses/by/4.0). 